\title{
An Empirical Study on Irregular Migration in Ethiopia: Policy Perspective
}

\author{
Petros Gebre Borojo \\ Noble College, Department of Human Resource
}

\begin{abstract}
Developing countries such as Ethiopia face cross border irregular migration which is mainly triggered by push and pull factors. In spite of this fact, not much is known on many of the recent aspects of irregular migration and few studies have been conducted on the incidence. Since irregular migration is getting more and more severe in Ethiopia, it needs investigation on its causes and consequences from policy perspective. Therefore, this study was aimed to conduct an exploration on irregular migration from policy perspective in the Southern Ethiopian Region. From this region human traffickers and human smugglers use three outlets such as the southern outlet to South Africa via Kenya, Tanzania and Mozambique, the north western outlet to Europe via Sudan and North Africa, and the northeastern outlet to Arab countries. To achieve the objective this study employed an in-depth case study design. Both qualitative and quantitative data were collected from primary and secondary sources. Key informant people were purposely and randomly sampled to conduct an interview and questionnaire. Data was analyzed and interpreted by using descriptive statistical technique and empirical analysis. Socio-economic and political causes and consequences of irregular migration, policy gaps that contribute to the incidence, and policy implementation problems were explored in this study.
\end{abstract}

Keywords: Irregular migration; Policy; Cause; Consequence; Ethiopia

DOI: $10.7176 / \mathrm{PPAR} / 10-3-01$

Publication date:March $31^{\text {st }} 2020$

\section{Introduction}

International Organization for Migration (2010), International Council on Human Rights Policy (2010) and Vollmer (2011) define that irregular migration is relocation that happens violating the current standards and strategies set up by nations to manage movement of migrants into and out of their territories. It is additionally characterized as the movement that happens outside the administrative standards of the sending, travel and accepting countries (Teshome et, al., 2013). From the viewpoint of goal nations, irregular migration is illegal entry, stay or work in a nation, implying that the transient does not have the important approval or reports required under migration directions to enter, live in or work in a given nation and from the point of view of the source nation, the inconsistency is seen, for example, in cases in which individuals cross a universal limit without legitimate international ID or travel record or does not satisfy the regulatory necessities for leaving the country (United Nations, 2011).

Despite the fact that variety in the economic, political and social settings limits speculations, certain components of irregular migration are pretty much all inclusive happened. There is general understanding that economic components are significant in prompting people to move irregularly from moderately poor nations to nations with high gross national product per capita (Collyer, 2015). Along these lines broad destitution and wage disparity exist with regards to a worldwide correspondences upset, with universal phone and web systems, worldwide TV slots et cetera. It is believed that these new technical possibilities to connect with far-away countries give good opportunities for potential migrants to take travel decisions.

Irregular migration has many structures and the refinements between them and additionally covers are vital for policy makers and practitioners (United Nations, 2011). In spite of having several forms of irregular migration, this study focuses on human smuggling and human trafficking that contribute to irregular migration. Many people agree that there is a widespread belief in the society that most migrants are tricked by traffickers and smugglers. It is possible to point that most smuggled irregular migrants know quite well what to expect (Teshome et, al., 2013). So this concerns not only the costs and non- monetary risks involved with irregular migration, but also the oftentimes very poor living conditions in the host countries.

Human smuggling is a type of migrant movement that is facilitated with the agreement of the migrant and usually with payment from the migrant for the smuggling services; it can be exploitive and risky, including deadly, however is not coercive in the feeling of trafficking (International Organization for Migration, 2010, Blue Campaign, 2016, The Guardian, 2016 and U.S.Immigration and Customs Enforcement, 2016).

As to United Nations (2013), Blue Campaign (2016), Skeldon (2000) and Wikipedia, the Free Encyclopedia (2016) human trafficking reveals itself in various ways; it incorporates the enrollment, transport, exchange, harboring or receipt of a man by assortment of means; the methods are utilizing power, misleading, and pressure, mishandle of force or position of weakness with the end goal of exploitation. In this manner, in the words enlisting them at a lowest payment, the exploitation of the prostitution of others or other forms of sexual exploitation, forced 
labor or services, slavery or practices similar to slavery are among the sufferings of the victims of human trafficking. Trafficking in individuals is not another issue; notwithstanding, it seems to have extended in many parts of the world and expected an inexorably world problem (Laczko, 2002). Currently, this problem has attracted growing world attention. Researchers and policy makers from various nations and global bodies have attempted to blend their ways to deal with trafficking; a typical definition has demonstrated vital (Laczko, 2002). In fact, the universal definition of trafficking as a distinct phenomenon has emerged only in recent years. International Organization for Migration, (2009) states that until the mid-1990s, trafficking was frequently seen as a type of human smuggling and a sort of illicit migration. A reasonable and particular worldwide meaning of trafficking has just been accessible since the December 2000 marking of the United Nations Protocol to Prevent, Suppress, and Punish Trafficking in Persons, which lays out the accompanying: Trafficking face to face might mean the enrollment, transportation, exchange, harboring or receipt of people, by method for the danger or utilization of constrain or different types of pressure, of kidnapping, of extortion, of trickiness, of the mishandle of force or of a place of defenselessness or of the giving or getting of installments or advantages to accomplish the assent of a man having control over someone else, with the end goal of exploitation (Laczko, 2002).

These days, there is a common comprehension on by far most of cases trafficking has turned into a corrupt mode of movement, which changes apparently lawful transitory ventures into frightful and unpredictable migration (United Nations, 2013).

"Irregular migration is of diverse social and economic consequences not only on the areas of origin, transit and destination, but also on the migrant themselves. Irregular migration endangers the lives of the migrants concerned where large but unknown numbers of people die each year trying to cross land and sea boarders without being detected by the authorities. Smugglers may extract a high price from migrants, sometimes charging thousands of dollars. The means of transport used by migrant smugglers are often unsafe, and migrants who are travelling in this way may find themselves abandoned by their smuggler and unable to complete the journey they have paid for." (Teshome et, al., 2013).

More generally, Teshome et, al. (2013) elaborates that people who enter or remain in a country without authorization can be at risk of exploitation by employers and other exploiters and it is argued that because of their irregularity, migrants are often unable to make full use of their skills and experience once they have arrived in a country of destination. They note that the various physical and psychological violence that the irregular migrants are suffering from. Ethiopia particularly southern region is not exceptional to this phenomenon where migration is initiated by both pull-push factors such as human smuggling and human trafficking.

As irregular migration is getting more and more severe in Ethiopia, it needs deeper researches on its causes and consequences from policy perspective. However, the studies conducted so far are scanty and are not comprehensive. Hence, this study seeks to fill the existing gaps. As trafficking is masked by the larger dynamics of human migration, the causes of trafficking in part are related to factors for migration like poverty, unemployment, and hope of securing better life in the prospective destination countries (Teshome et, al., 2013). In addition to that lack of awareness on the legal migration process and preference for swifter migration ways were identified as causes of human trafficking and consequences of irregular migration include political, physical, psychological and socio-economic turmoil (Wakgari, 2014).

In Ethiopia a few studies have been conducted on causes and socio-economic impacts of illegal migration. The studies that conducted so far on this issues; however, are not sufficient, not without limitations and no study is conducted by using more relevant comprehensive research methods. Moreover, no study has been conducted in relation to policy gaps and efficiency and effectiveness of policy implementation.

Wakgari (2014) in his study "study on Causes and Consequences of Human Trafficking in Ethiopia: The case of Women in the Middle East countries" used feminist qualitative method of analysis employing primary and secondary data. In spite of the fact that the problem of irregular migration is a wide problem including men and women, he emphasized on women migrating to Middle East countries. However, the problem of irregular migration is a wide problem including men and women. Therefore, emphasizing on women as a target group will not give clear and comprehensive output and it would be difficult to draw policy remedy based on the study. In addition, Endeshaw et, al. (n.d) in their study "Assessment of trafficking in women and children in and from Ethiopia" tried to gather in-depth information on the extent and character of trafficking in and from Ethiopia, including the magnitude and prevalence of the problem, the profile of victims and perpetrators, methods of recruitment, routes and means of transportation used and forms of abuse and exploitation faced by victims of irregular migrants. Emebet (n.d) assessed international labor migration situation taking women migration in Ethiopia. As similar to Endeshaw et, al. (n.d) she emphasized on the assessment without considering its socioeconomic, political, psychological and physical consequences.

Therefore, this study tries to fill the existing gaps described above by analyzing the causes and consequences of irregular migration in the Southern Ethiopian Region and describing policy gaps of irregular migration and its implementation problems. 


\section{Review of Related Literatures}

\subsection{Concept and Meaning of Irregular Migration}

Meanings of irregular migrants are problematic and complex; for inexact similarity among nations, two broad types of irregularity have been distinguished in the database: irregular foreign residents and irregular foreign workers (International Labor Organization, 2011 and Koser, 2005). As to International Labor Organization irregular foreign residents are outside nationals with no legitimate inhabitant status in the nation they are dwelling in, and people abusing the terms of their status so that their stay might be ended whereas irregular foreign workers are outside nationals working in the shadow economy, incorporating those with a customary habitation status who work without enrollment to stay away from due charges and regulations.

The term irregular migration commonly alludes to the cross-border stream of individuals who enter a nation without that nation's legitimate consent to do so (Vollmer, 2011). Conversely, the term irregular migrants normally alludes to the load of transients in a nation who are not qualified for dwell there, either on the grounds that they have never had a legitimate habitation allow or on the grounds that they have outstayed their time-restricted permit (International Organization for Migration, 2011). Irregular migration is movement that happens outside the administrative standards of the sending, travel and getting nations. There are no certain or all around acknowledged meaning of irregular migration. Thus, from the point of view of goal nations it is section, stay or work in a nation without the essential approval or archives required under movement controls. From the point of view of the sending nation, the inconsistency is for instance found in cases in which a man crosses a global limit without a substantial international ID or travel archive or does not satisfy the authoritative necessities for leaving the nation. There is, in any case, an inclination to limit the utilization of the expression illegal relocation to instances of smuggling of migrants and trafficking in persons.

\subsection{Theoretical Review}

As to E-source (n.d) theories are set of interrelated concepts, definitions, and propositions that explain or predict events or situations by specifying relations among variables. They present a systematic way of understanding events, behaviors and/or situations. Hence, they give various views through which to look at problems and relating variables, focusing attention on different aspects of the data and providing a framework within which to conduct analysis. Therefore the following theories guide research process and illuminate their findings.

\subsubsection{New Public Management Theory}

New public management is an arrangement of practically every administration apparatus observed to be appropriate for public sector; it is essential policy instrument in enhanced government performance (Hood, 1995 and Fatemi and Behmanesh, 2012). So it is a subset of all policy performance, not a divisible arrangement of specialized endeavors. Thus, the reforms that eventually ensued emphasized not only significant down-sizing, but also significantly improved management capabilities. Moreover it emphasizes the importance of securing highest level of political authority to reform programs. Equally important is the institutionalization within the government performance skills necessary for the continuation and development of good management in government. There should be sufficient political will to implement such reforms.

Organization for Economic Cooperation and Development (1995) stated that it is helpful to consider New Public Management not as, a management reform ideology movement or trend but rather as a set of tools, any of which may be applied(or not) in particular settings. Therefore, the outcome is a public-sector that is more capable of continuous improvement than was previously the case. If New Public Management reforms are to be effectively implemented, require an all-encompassing methodology, integrating the multiple human resources, financial, technical, and structural factors involved within a dynamic environment.

\subsubsection{The Social Capital (Network) Theory}

For the social capital theory migration is brought about by interpersonal organizations between the place of root and the objective (Mohammed, 2016). Thusly, movement systems are considered as a social capital where individuals from the system have the privilege to get data and different backings that makes relocation more advantageous by expanding the additions and bringing down the expenses. Companions and relatives at goal fill in as wellsprings of data about the open doors, dangers and difficulties related with relocation. He/she furthermore help new homeless people to settle in viably by offering lodging and distinctive backings. In addition, the closeness of mates or relatives at objective makes the psychic cost of moving to somewhere else lower. Along these lines, migration ends up being all the more engaging for individual with systems at goal. Along these lines, migration ends up being all the more charming for individual with systems at goal nation. It is expressed that systems could likewise be at a larger amount like group. People from groups that are emphatically associated with the goal have simple access to data and will get bolster after they moved. Family, friendship, and gathering systems underlie an incredible piece of the present movement to industrial nations. Current enthusiasms for these frameworks run with the change of a migration system perspective and the creating awareness of the substantial scale and little scale determinants of development (Boyd, 1989). In this way, systems at different levels add to irregular migration. 


\subsubsection{Neo-classical Economic Theory}

Neo- classical Economic Theory communicates that overall development (legal and unlawful) is a cash sparing favorable position decision endeavored by a man remembering the ultimate objective to increase expected wage (Massey et, al., 1994). In this manner, expected wage is described as the likelihood of business times the mean wage. For undocumented workers, anticipated that salary needs would be further multiplied by the likelihood of effectively entering the goal nation and the net pick up from movement is described as the distinction between expected wage in the home and goal nations, summed and marked down for a period skyline and added to the negative cost of migration. They believe that individuals will be prompted to migrant when the net gain is positive. Subsequently the fundamental determinant for clarifying universal movement is the wage differentials that exist amongst home and goal nations.

\subsubsection{The New Economics of Labor Migration Theory}

The new economics labor migration theory expresses that universal migration happens from failures in other markets that threaten the material well-being of households and create barriers to their economic advancement (Massey et, al., 1994). This theory allows for markets to have imperfections. This recognizes that in developing countries markets are not fully matured or well-functioning. With a specific end goal to self-guarantee against risks to income, production, and property, or to gain access to scarce investment capital families send at least one worker to outside work markets.

The migration literature additionally delivers the fragmented labor market theory. This theory expresses that immigration is driven by demand built into the economic structure of the well-developed industrial societies. As the literature in the well developed markets we see a labor market which on one hand offers jobs with high pay, benefits, good working conditions, while on the other hand we see a secondary job market characterized by low pay, few to no benefits, hazardous or unpleasant working conditions and instability. Typically, within the developed society, natives are not willing to take these jobs in the secondary market where there is little to no return to education, experience, or skill. Thus the shortage of laborers encourages irregular migration.

\section{Methodology}

\subsection{Research Design}

This study employed an in-depth case study method. Case study is defined as an empirical inquiry that investigates a contemporary phenomenon within its real-life context, especially when the boundaries between phenomenon and context are not clearly evident (Yin, 2003).

'Typically, a case study examines the interplay of all variables within the site of interest in order to provide as complete an understanding as possible. The case study is particularly relevant in policy research because its flexibility allows researchers to begin with relatively broad research questions, and narrows down their focus during the process of data collection and analysis. This feature is especially suitable to policy research given the complexity of the social problem and unpredictability of the policy outcome"' (Yin, 2003).

\subsection{Data Type and Sources}

Both qualitative and quantitative data was collected from primary and secondary sources. Quantitative data includes numerical data about the explanatory variables in the study. Primary data was gathered directly through questionnaire and interview whereas secondary data was gathered from administrative laws, declarations, reports, and guidelines by using document analysis. Using multiple sources of data increases not only the reliability and validity of the data in this study but also the confidence in findings. For primary data collection the researcher used purposive sampling technique to select sample administrative districts. Based on Central Statistics Agency of Ethiopian (2007) total population of Southern Ethiopian Region is 14,929,548 with 18 administrative districts. As a result, Hadiya zone (total population 1,231,196), Kembata Tembaro zone (total population 680,837), Silte Zone (total population 750,398) and Halaba Special woreda (total population 320,060) are sampled administrative districts . From each of these districts 60 community members and other stakeholders, 10 expert interview respondents and 10 expert questionnaire respondents were randomly sampled populations of the study. Therefore, 260 people are total sample population of this study.

\subsection{Data Analysis}

\subsubsection{Descriptive Statistical Technique}

To maintain reliability and validity of the collected data, researcher accomplished a task of data editing, coding and entry. Both in house and field editing was used. The collected data was processed and analyzed by classifying into its homogeneity of responses. The collected data was analyzed and interpreted by using descriptive statistical analysis techniques such as tables and figures.

\subsubsection{Empirical Analysis}

Empirical data analysis was used in this study in order to assess the causes and impacts of irregular migration. The binary logistic regression model was used to see how much the independent variables affect the dependent one. 
The dependent variable is migration status $(1=$ victim of irregular migration and $0=$ non-migrant $)$. The independent variables included in the main regression model are education level, age, large family size, shortage of farm land, gender disparity, chronic unemployment and underemployment, earning capacity and income level (poverty), civil unrest and political instability, need for material improvement, wage benefit differences at origin and destination area, social network abroad, awareness lack of burden caused by irregular migration, wish to basic needs fulfillment, lack of loan facility, negative attitudes towards local domestic works and limited law enforcement on the incidence. In assessing causes and impacts of irregular migration, it is imperative to consider the role of these explanatory factors.

\section{Result and Discussion}

\subsection{Status Quo of Irregular Migration in Ethiopia from 2011-2016}

Ethiopian women migrating to the Middle East as domestic workers, which also often occurs through trafficking and smuggling is one of biggest and as of late universal movement flows (International Organization for Migration, 2009). International Organization for Migration says on account of Ethiopian women setting off to the Middle East, the underlying movement choice is made by their own particular unrestrained choice and further planned through intermediaries and facilitators. Horwood (2015) and Danish Refugee Counsel (2016) illustrated that they are, in any case, given falsehood in regards to the position and conditions sitting tight for them in the host nation. In the last six years (2011-2016) an estimated 396,640 Ethiopians arrived on Yemen's shores, an average of over 66,107 per year. In the most recent six years (2011-2016) an expected 396,640 Ethiopians landed on Yemen's shores, a normal of more than 66,107 for each year (Anbesse et, al., 2009). The principle goals are Lebanon, Saudi Arabia, Yemen, and the United Arab Emirates; and women trafficked to the Middle East are by and large between 20-30 years old and children as youthful as 13 are additionally trafficked. The women who migrate are living under poverty, and some have completed high school. Most of the women being internationally trafficked and smuggled are from urban areas with a large number coming from Addis Ababa. Women and youngsters who move to the Middle East will regularly utilize a vacationer visa and claim to go for a religious journey or holy travel. In the past they would fly directly from the Addis Ababa airport. Due the opening of an immigration office at the airport that requires people to show work permits before they leave, but currently it is more common for people to go to neighboring countries before departing. This makes it more difficult for the government to track its citizen's migration.

Anbesse et, al. (2009) in their study indicates that Ethiopian migrant women working as domestic workers in the Middle East are known as suffering inadequate working conditions and physical and sexual abuse. Women have described having their passports taken away so they cannot leave, they are expected to work 24 hours per day, and they cannot contact with other Ethiopians and it described how this condition leads to social defeat of the migrant women. From 1999-2005 the Quarantine Office of the Addis Ababa International Airport revealed 129 female bodies came back from Jeddah, Dubai, and Beirut. So this infers us the risk and troubles irregular migrants confront from.

Figure 1: Ethiopian Arrivals into Yamen from 2011-March, 2016

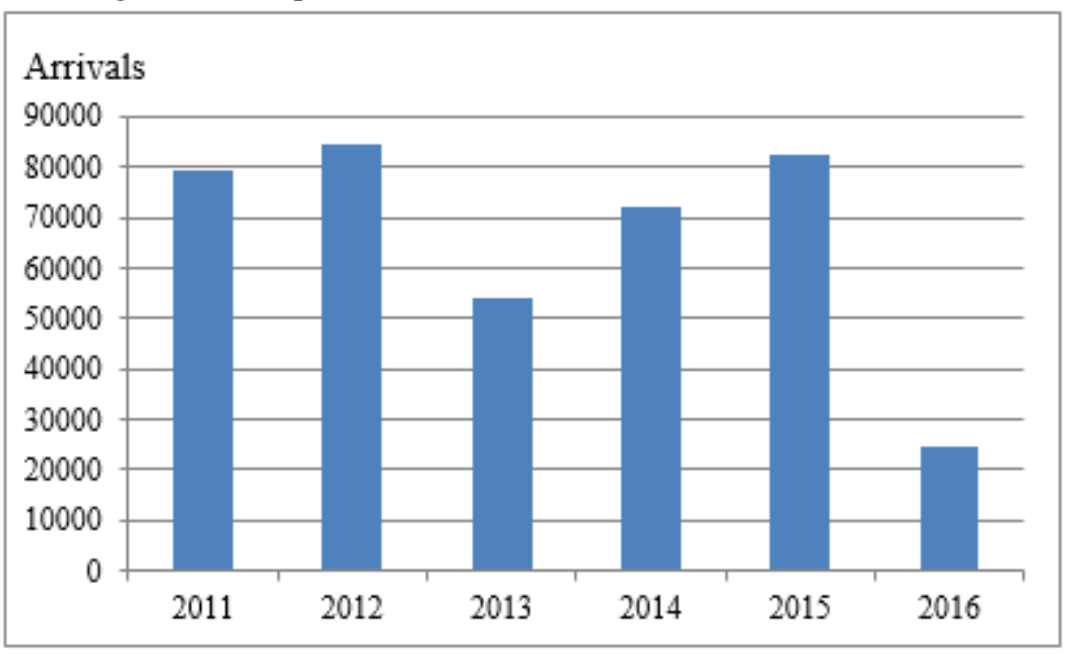

Source: UNHCRS, 2010

In the Ethiopian setting, migration from Ethiopia to Europe has been given significantly less consideration than migration to Saudi Arabia and Yemen. In 2011 the International Labor Organization (2011) was given numbers from the Ethiopian Ministry of Foreign Affairs recommending that there were in the vicinity of 75,000 and 100,000 Ethiopians going to Libya every year to touch base at European countries. More recently, Play 
Therapy Africa Ltd (2011) estimates that between 50-100 Ethiopian migrants cross into Sudan per day, which would mean somewhere between 18,000 and 37,000 per year. The journey from Addis Ababa to Khartoum is estimated to take between 3-6 days and cost migrants United States Dollars 500-800 (United Nations High Commissioner for Refugees, 2010). In spite of the high numbers of Ethiopian migrants and refugees, little is known about their journeys from Ethiopia to Sudan. ILO claims that routes which are recently being used to reach Sudan goes through Wollega, Metemma and Gambela. Traffickers and smugglers use these routes to avoid being intercepted by officials. In 2012, the government set up a 'National Committee against Trafficking', and Ethiopia regards itself as being tough on migrant smuggling and trafficking, and so tries to regulate the recruitment market for labor migrants. With increased emphasis on prosecuting and punishing the government intends to control migration and protect vulnerable migrants and refugees (Messele and Gebeyehu, n.d.). However, there is still a great deal of people irregularly migrating via this route.

Ethiopian migrants are found on irregular flows along the Southern corridor from the Horn of Africa towards South Africa transiting via Kenya, Tanzania and other countries in southern Africa. Available literatures show that the flow of Ethiopians to Republic of South Africa became noticeable beginning from 1991 after the fall of the Dergue regime (International Organization for Migration-IOM, 2016). The change in government and the end of apartheid in early 1990s in Republic of South Africa increased the migration of youth. The International Organization for Migration-IOM report further underlines that approximately 65,000 to 70,000 of Ethiopians make their home in Republic of South Africa. These numbers are increasing every week due to the influx of new arrivals, mainly from large-scale, successful smuggling operations in Ethiopia and over 95\% of them enter South Africa through irregular means and regularize their situations rapidly through its asylum policies. Horwood (2015) explains that in Kenya itself, there are modest numbers of Ethiopian refugees $(21,300)$, asylum seekers $(8,900)$ and a suspected larger number of irregular economic migrants living in cities and towns, evading authorities. In 2009, it was estimated that more than 10,000 Ethiopian migrants are smuggled on this route every year from Ethiopia to South Africa (Danish Refugee Counsel, 2016). Clear and updated figures are not available.

Figure 2: Estimated Yearly Arrivals of the Three Outlets

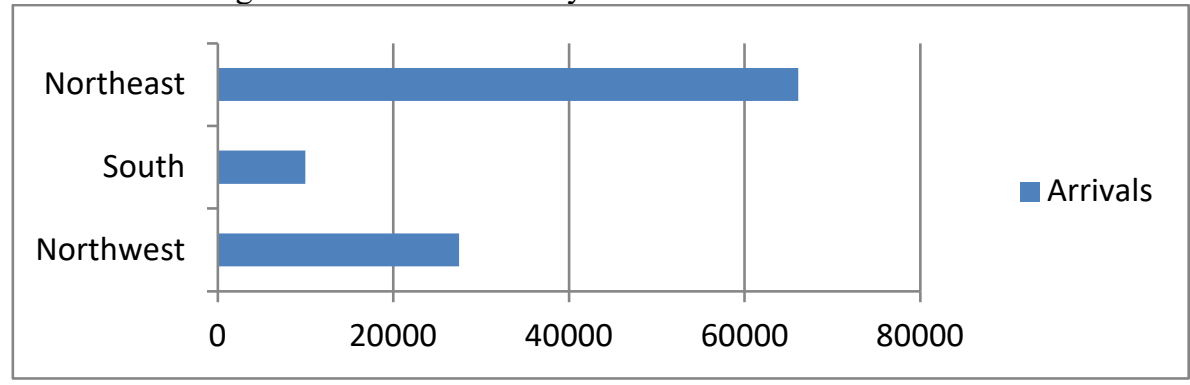

Source: Calculated by the author from gathered data

\subsection{Observed Problems before Actual Data Gathering}

\subsubsection{Rate of Irregular Migration in Southern Ethiopian Region}

As to International Organization for Migration-IOM (2009) after 1991, the fall of the military regime, many Ethiopians particularly from the southern region have been illegally immigrating to foreign states through the southern outlet to South Africa, the North Eastern outlet to Arab countries, and the North Western outlet to Europe countries. Although a state-led industrial drive has transformed Ethiopia into one of Africa's fastest-growing economies, a third of its 99 million citizens still survive on less than 1.90 United States Dollar a day (World Bank, 2015). Unemployment rate in this region is $18 \%$ at urban and $20.6 \%$ at rural. So these factors contribute to irregular migration in the region. The number of irregular migrants has increased 23 per month in 2008 to 410 per month in 2014. Basically irregular migration may have several ways; however, in Ethiopia it is initiated by pull-push factors such as socioeconomic and demographic variables; and it is run by human smugglers and human traffickers.

\subsubsection{Image of Country and Loss of Public Trust}

As irregular migration is getting more and more terrible phenomena in Ethiopia, then it has affected not only the profile of the country but also the migrants, their families and the society they belong to. Literatures share that economic exploitation, physical and psychological abuse that migrant victims confront at the destination countries are commonly known problems which are caused by irregular migration in Ethiopia. Many irregular migrants die from either hazards of their journey or manmade factors including killings. Available literature indicates that many irregular migrants face robbery and wage irregularity at the goal nations; so that these have brought about emotional fear and loss of self-confidence. Families of migrant victims have been affected by irregular migration as well. They confront from economic crisis in a way that they spend a lot of money to afford their son's/daughter's journey assuming that they would be refunded by the migrant after he/she arrives at the destination and gets a job. In contrast this has increased economic dependency and social crisis. Therefore, these things messed up the image 
of the country and the government might have lost public trust and confidence.

\subsection{The Existing policies that Fight against Irregular Migration in Ethiopia 4.3.1. Ethiopian Proclamation of Irregular Migration}

As indicated by Federal Negarit Gazette (2015) of Federal Democratic Republic of Ethiopia Prevention and Suppression of Trafficking in people and smuggling of migrants' announcement section 2, number 3 trafficking face to face is punishable. Along these lines, if (1) any individual with the end goal of misuse, with in the domain of outside of Ethiopia; (2) at the appearance of local or abroad business or sending to another country for work or apprentship; (3) by finishing up appropriation understanding or at the affection of reception; or (4) for whatever other reason utilizing danger or compel or different methods for pressure, kidnapping, extortion, double dealing, guarantee, manhandle of force or by utilizing the defenselessness of a man or enrolls, transports, exchanges, harbors or get any individual by giving or getting installments or advantages to accomplish the assent of a man having control over someone else might be culpable with thorough detainment from 15 years to 25 years and with fine from 150000 to 300000 Ethiopian birr.

If this crime is (1) committed against child, women or any one with mental or physical impairment; (2) brought about physical or mental mischief on the victim; (3) conferred by utilizing medications, prescriptions or weapons as a methods; (4) submitted by open official or government worker in manhandling force; or (5) submitted by a man who is parent, sibling, sister, a gatekeeper, or a man having a power on the casualty; the discipline should be thorough detainment of at least 25 years or lifelong imprisonment and with fine from 200,000 to 500,000 Ethiopian birr.

As to Federal Negarit Gazette of Federal Democratic Republic of Ethiopia Prevention and Suppression of Trafficking in persons and smuggling of migrants proclamation part 2 number 4 , for the reason for advancing human trafficking any individual who: (1) allows his home building or different allows in his own particular name or his own particular control to be utilized for human trafficking purposely or should have known; (2) distributes, stores, spreads, imports, or fares any production; (3) oversees, runs or funds by sorting out any occupation enlistment organization; (4) intentionally orchestrates transportation, transports or encourages the transportation of casualty via land, ocean or air; (5) helps, produces, gives, holds and distorts character card or travel archive or help to get these records through unlawful means for the advantage of other individual ;or (6) holds as obligation subjugation, commandingly grabs, hides, obliterates or causes to demolish the casualty's personality card or travel reports to limit his entitlement to development or access to open administration, shall be punished with rigorous imprisonment from 15 years to 25 years and with fine from 150,000 to 300,000 Ethiopian birr.

In case of human smuggling Federal Negarit Gazette of Federal Democratic Republic of Ethiopia Prevention and Suppression of Trafficking in persons and smuggling of migrants proclamation part 2 number 5 describes that (1) any individual either straightforwardly or in a roundabout way with the expectation to create money related or other material advantage, who causes transients to cross outskirt, endeavors to cross or get ready to cross into or out from the domain of Ethiopia illicitly might be rebuffed with imprisonment of 15 years to 20 years and with fine from 150,000 to 300,000 Ethiopian birr. If this crime is (a) carried out against children, women or any one with mental or physical impedance; (b) brought about physical or mental mischief on the victim; (c) is perpetrated by a man who has comparable criminal record; or (d) carried out by open official or government employee in mishandling power; the discipline might be thorough detainment of at the very least 20 years and with fine from 300,000 to 500,000 Ethiopian birr.

Federal Negarit Gazette of Federal Democratic Republic of Ethiopia states punishments concerning offenses identified with personality card or travel records expresses that any individual who produces, forms, gives or exchanges false character card or travel archives to pirate transients to go into or escape from the region of Ethiopia via land, ocean or air, might be culpable with thorough detainment at the very least 10 years not surpassing 20 years and with fine from 100,000 to 200,000 Ethiopian birr.

Prevention and Suppression of Human Trafficking and human Smuggling Proclamation of Federal Democratic Republic of Ethiopia are considered as a legal document for law enforcement rather than comprehensive tool to fight against irregular migration. It focuses on penalty issues of human traffickers and human smugglers. This document doesn't have responsibility breakdowns of government officials at local level and other stakeholders and cross-checking directions. So it is difficult to know who is accountable for the prevention of the problem because there is no cross-checking hierarchy between or among government officials.

\subsection{The Existing Policy Gaps to Fight against Irregular Migration}

Federal Democratic Republic of Ethiopia Prevention and Suppression of Trafficking in persons and smuggling of migrants' proclamation is the country's basic tool to fight against irregular migration; however, it isn't without limitation. One and big gap that negatively affected legal migration is the absence of border management strategies such as how to strengthen physical borders (fences, electronic surveillance), documentation and enhancing security feature, border controlling system and inspections, training border guards and using modern checking machines. 
Despite the fact that the proclamation is legal framework to fight against the problem it lacks clear and organized hierarchy of public officials who are responsible for taking actions on the incidence. Human beings seek accountability; they want to know who is responsible for certain actions and who is accountable for the consequences of those actions. By accountability is meant the imperative to make public officials answerable for their actions and responsive to the entity from which they derive their authority. Accountability also means establishing criteria to measure the performance of public officials, as well as oversight mechanisms to ensure that standards are met. Therefore, in the absence of clear and organized hierarchy of public officials from local level to higher level it is difficult to maintain accountability system so that government officials become careless and laissez-faire in fighting against irregular migration.

Besides, Federal Democratic Republic of Ethiopian Government has no anti-netlist (child number limiting policy). Families having limited number of children are more likely to have higher incomes, increased home value, greater savings and assets, higher educational achievement, and improved access to basic needs. Education helps to overcome poverty by increasing literacy and preparing people for innovation and job creation. Once family's livelihood improved, then the probability of irregular migration is relatively decreased.

\subsection{Policy Implementation Analysis of Southern Ethiopian Region}

Table 1: Measures Relating to Border Management

\begin{tabular}{|c|c|c|c|c|c|c|c|c|}
\hline \multirow{2}{*}{$\begin{array}{l}\text { Measures relating to border } \\
\text { Management }\end{array}$} & \multicolumn{2}{|c|}{ not good } & \multicolumn{2}{|c|}{ Good } & \multicolumn{2}{|c|}{ very good } & \multicolumn{2}{|c|}{ Excellent } \\
\hline & Freq. & $\%$ & Freq. & $\%$ & Freq. & $\%$ & Freq. & $\%$ \\
\hline $\begin{array}{l}\text { Physical borders (fences and } \\
\text { electronic surveillance) }\end{array}$ & 14 & 70 & 3 & 15 & 1 & 5 & 2 & 10 \\
\hline Enhanced security feature & 16 & 80 & 1 & 5 & 2 & 10 & 1 & 5 \\
\hline Border controls and inspections & 15 & 75 & 2 & 10 & 3 & 15 & 0 & 0 \\
\hline Trained border guards & 12 & 60 & 4 & 20 & 2 & 10 & 2 & 10 \\
\hline Modern checking machines & 16 & 80 & 2 & 10 & 1 & 5 & 1 & 5 \\
\hline
\end{tabular}

Source: Field survey Dec, 2016

Data on table 1 shows that $14(70 \%)$ of respondents believe physical borders such as fences and electronic surveillance are not good. Regarding enhanced security feature majority or $16(80 \%)$ respondents chose the option not good. For item border controls and inspections 15 (75\%) responded 'Not good", 2 (10\%) 'Good" and 3 (15\%) "'Very good". 12 (60\%) responded "Not good", $4(20 \%)$ "'Good", $2(10 \%)$ " "Very good" and 2 $(10 \%)$ ' 'Excellent' for item related with trained border guards. Based on this data $16(80 \%)$ of total respondents said modern checking machines are not good, 2 (10\%) responded 'Good', 1 (5\%) said ''Very good' and 1 (5\%) responded ''Excellent'. Hence, border management problem affected the efficiency of policy implementation.

Table 2: Degree to which Data is Collected on the Incidence of Migration

\begin{tabular}{l|ccc}
\hline Degree to which data is collected & Freq. & Percent & Cum. \\
\hline Never & 1 & 5 & 5 \\
Sometimes & 15 & 75 & 80 \\
Usually & 4 & 20 & 100 \\
\hline Total & 20 & 100 & \\
\hline
\end{tabular}

Source: Field survey Dec, 2016

Table 2 depicts that $1(5 \%)$ of respondents replied that data is never collected on the incidence of irregular migration. According to $15(75 \%)$ of respondents data is sometimes collected on the incidence of irregular migration. 4 (20\%) of total respondents believe that data is usually collected on the incidence of irregular migration. Available evidence shows that data collection on the incidence of irregular migration is conditional. When the problem seems serious they gather information and take an action. They also stated that there is no birth and death registration at municipal level so that this hinders data collection on the problem. Therefore, fluctuation of data collection on the incidence of irregular migration affected policy implementation efficiency.

Respondents' evidence shows that they don't work with a local religious community or congregation to help stop trafficking by supporting a victim service provider or spreading awareness of human trafficking. The offices' reporting, investigation and prosecution of irregular migration cases have not been satisfactory because they didn't organize reporting hierarchy from local to higher authority and there is no cooperation and coordinated work among them. Despite the fact that no timely arranged reporting and investigation, they brought 49 traffickers and 63 smugglers to court and they are sentenced to 20-25 years imprisonment and 250,000-300,000ETB as fine. Yet they were investigated and prosecuted, the problem still exists; it needs commitment, institutionalizing and cooperation among local and higher stakeholders. It is hard to say they are efficient; they are planning to develop organized and institutionalized work on the incidence of irregular migration. Therefore, Police, immigration affaires department, judicial officials, women and children affaires office as well as other concerned stakeholders need to work in collaboration and commitment. 
Table 3: Degree to which Policy is Implemented Effectively

\begin{tabular}{l|ccc}
\hline Policy implementation effectiveness & Freq. & Percent & Cum. \\
\hline Fair & 4 & 20 & 20 \\
Good & 2 & 10 & 30 \\
Low & 13 & 65 & 95 \\
Very good & 1 & 5 & 100 \\
\hline Total & 20 & 100 & \\
\hline \multicolumn{4}{c}{ Source: Field survey Dec, 2016}
\end{tabular}

Source: Field survey Dec, 2016

As it is indicated on table 3 policy implementation effectiveness is low. Thus, for the item policy implementation effectiveness 1 (5\%) of respondents replied ' 'Very good', 2 (10\%) 'Good', 4 (20\%) 'Fair' and 13 (65\%) 'Low'. Therefore, majority of the respondents believe that policy implementation effectiveness is low. Based on this evidence it is possible to conclude that policy implementation effectiveness is not satisfactory in Southern Ethiopian region.

Table 4: Obstacles to Effective Policy Implementation

\begin{tabular}{l|cc|c}
\hline \multicolumn{1}{c|}{ Obstacles to effective policy implementation } & Freq. & $\%$ & Total \\
\hline Limited financial resource & 14 & 70 & \\
Limited human resource & 17 & 85 & \\
Limited cooperation among higher and local authorities & 15 & 75 & \\
No training in specialized areas such as detection of forged (falsified) & 19 & 95 & \\
documents at border area & 18 & 90 & 20 \\
No civil registration of birth, marriages, and death in Ethiopia & &
\end{tabular}

\section{Source: Field survey Dec, 2016}

Evidence on table 4 indicates that shortage of financial resource limits capacity of policy implementation effectiveness. This idea was supported by majority of the respondents. In addition to this limited human resource and limited cooperation and collaboration among higher and local government officials are factors that affected effectiveness of policy implementation. Beyond these, lack of training in specialized areas such as detection of forged (falsified) documents at border area is among obstacles to effective policy implementation. Furthermore, respondents' evidence shows that there is no civil registration of birth, marriages, and death in Ethiopia and this affected effective policy implementation. As a result, these obstacles negatively affected effectiveness of policy implementation of irregular migration.

\subsection{Cause Analysis of Irregular Migration}

\subsubsection{Socio-economic and Political Causes of Irregular Migration}

Available literatures share that the net flow of irregular migration pattern is almost entirely from countries of lower socioeconomic levels to countries of higher socioeconomic levels, and particularly from developing countries to developed countries. While there are still other causes associated with poorer countries, the most common motivation for irregular migrants is the pursuit of greater economic opportunities and quality of life in the destination state. This part of the study illustrates factors that contribute to irregular migration. 
Table 5: Result of Logistic Regression Model

\begin{tabular}{|l|l|l|l|l|}
\hline Migration status $(1=$ migrant, $0=$ non migrant) & Coef. & Std. Err. & z-value & P-value \\
\hline Education & -3.515 & 0.745 & -4.72 & 0.000 \\
\hline Age & -8.550 & 1.698 & -5.04 & 0.000 \\
\hline Large family size & 1.651 & 0.835 & 1.98 & 0.048 \\
\hline Shortage of farm land & 0.699 & 0.802 & 0.87 & 0.383 \\
\hline Gender disparity & -1.565 & 1.010 & -1.55 & 0.121 \\
\hline Chronic unemployment and underemployment & 10.583 & 2.153 & 4.92 & 0.000 \\
\hline Earning capacity and income level (poverty) & -1.949 & 0.924 & -2.11 & 0.035 \\
\hline Civil unrest and political instability & 1.180 & 0.929 & 1.27 & 0.204 \\
\hline Need for material improvement & 0.715 & 0.925 & 0.77 & 0.439 \\
\hline Wage benefit differences at origin and destination area & 3.758 & 1.158 & 3.25 & 0.001 \\
\hline Social network abroad & -0.312 & 0.802 & -0.39 & 0.697 \\
\hline Awareness lack of burden caused by irregular migration & 2.011 & 0.967 & 2.08 & 0.038 \\
\hline Wish to basic needs fulfillment & -0.349 & 0.892 & -0.39 & 0.695 \\
\hline Lack of loan facility & 4.235 & 1.446 & 2.93 & 0.003 \\
\hline Negative attitudes towards local domestic works & 1.883 & 0.935 & 2.02 & 0.044 \\
\hline Limited law enforcement on the incidence & 1.013 & 0.943 & 1.07 & 0.283 \\
\hline Constant & 16.947 & 5.139 & 3.3 & 0.001 \\
\hline $\begin{array}{l}\text { Number of obs. } \\
\text { LR chi2(16) } \\
\text { Pseudo R2 }\end{array} \quad 240$ & 222.94 & & \\
\hline
\end{tabular}

Result on Table 5 shows that education level, age, large family size, migrant's awareness lack of burden that is caused by irregular migration, negative attitudes towards local domestic works in the origin country, poverty and under development, wage benefit differences at the origin country and destination area, and lack of loan facility to begin jobs are socioeconomic factors that significantly cause irregular migration in Southern Ethiopian Region at $5 \%$ and $1 \%$ level of significance. On the other hand, civil unrest and political instability as a political factor found to be statistically insignificant factor. Therefore, it doesn't contribute to irregular migration in Southern Ethiopian region. The following part deals with detailed description of each factor based on its marginal effect.

Table 6: Marginal Effect of Logistic Regression

\begin{tabular}{|l|c|c|c|c|}
\hline dy/dx & Coef. & Std. Err. & z-value & p-value \\
\hline Education & -0.153 & 0.019 & -8.23 & 0.000 \\
\hline Age & -0.372 & 0.039 & -9.60 & 0.000 \\
\hline Large family size & 0.072 & 0.034 & 2.08 & 0.037 \\
\hline Shortage of farmland & 0.030 & 0.034 & 0.88 & 0.376 \\
\hline Gender disparity & -0.068 & 0.043 & -1.60 & 0.110 \\
\hline Chronic unemployment and underemployment & 0.460 & 0.052 & 8.88 & 0.000 \\
\hline Earning capacity and income level (poverty) & -0.085 & 0.037 & -2.26 & 0.024 \\
\hline Civil unrest and political instability & 0.051 & 0.040 & 1.29 & 0.197 \\
\hline Need for material improvement & 0.031 & 0.040 & 0.78 & 0.438 \\
\hline Better wage benefit at destination country & 0.123 & 0.030 & 4.06 & 0.000 \\
\hline Social network abroad & -0.014 & 0.035 & -0.39 & 0.696 \\
\hline Awareness lack of burden caused by irregular migration & 0.087 & 0.039 & 2.23 & 0.026 \\
\hline Wish to basic needs fulfillment & -0.015 & 0.039 & -0.39 & 0.694 \\
\hline Lack of loan facility to begin jobs & 0.184 & 0.056 & 3.26 & 0.001 \\
\hline Negative attitudes towards local domestic works & 0.082 & 0.038 & 2.14 & 0.032 \\
\hline Limited law enforcement on the incidence & 0.044 & 0.040 & 1.09 & 0.274 \\
\hline
\end{tabular}

Results on table 6 indicate that $1 \%$ increase in education level will produce a 0.15 units' decrease in the probability of irregular migration. As age increases in $1 \%$, the probability of irregular migration decreases in 0.37 units. On the other hand, individuals with large family size are expected to be $7 \%$ more likely to migrate compared to families with small members. Chronic unemployment and underemployment is cause for irregular migration. When unemployment problem decreases in Southern Ethiopian Region, the probability of irregular migration lowers in $46 \%$. Individuals with large earning capacity and income level are assumed to less likely migrate in comparison to those who have less earning capacity and small income level. That means the higher in earning capacity and income level the lower will be irregular migration. The following table illustrates average monthly income by migration status. 
Table 8: Average Monthly Income by Migration Status

\begin{tabular}{l|cccccc}
\hline \multicolumn{1}{c}{ Income in USD } & \multicolumn{2}{c}{ Victims } & \multicolumn{2}{c}{ Non-migrants } & \multicolumn{2}{c}{ Total } \\
& Freq. & $\%$ & Freq. & $\%$ & Freq. & \% \\
\hline $3.17-15$ & 18 & 25.7 & 35 & 20.6 & 53 & 22 \\
$15.1-28$ & 29 & 41.4 & 34 & 20 & 63 & 26.2 \\
$28.1-40$ & 11 & 15.7 & 39 & 23 & 50 & 21 \\
$40.1-55$ & 9 & 12.9 & 32 & 18.8 & 41 & 17 \\
$>55$ & 3 & 4.3 & 30 & 17.6 & 33 & 13.7 \\
\hline Total & 70 & 100 & 170 & 100 & 240 & 100 \\
\hline \multicolumn{7}{c}{ Source: Field survey Dec, 2016}
\end{tabular}

Beyond these if wage benefit increases at destination country, then probability of irregular migration will be increased in $12.3 \%$. This evidence is supported by Neo-classical economic theory stating that individuals will be prompted to migrant when the net gain is positive at the goal nation. Subsequently the fundamental determinant for clarifying universal movement is the wage differentials that exist amongst home and goal nations. The increases in awareness lack of burden and consequences of irregular migration on the state, immigrant themselves and their family will probably cause irregular migration in $8 \%$. The result shows that lack of loan and credit opportunity have robust positive impact on irregular migration. Individuals who get loan and credit opportunity to begin jobs have $18 \%$ less probability of irregular migration compared to individuals with no access to loan and credit. As indicated above negative attitudes towards local domestic works due to knowledge gap is referred to as a cause of irregular migration. As migrants' attitudes towards domestic works improved, the probability of irregular migration descends in $8 \%$.

\subsection{Consequences of Irregular Migration}

Available literatures show that irregular migration inflicts large negative impact; first and foremost it affects migrant and their families, and also the societies of which they are from. Miserable journey from the beginning to the destination, hazardous working and living conditions, and abuse and exploitation in the hands of traffickers and smugglers are among common impacts of irregular migration. Employers have significant and long lasting impact on the lives of victims as well. This section illustrates consequences of irregular migration.

\subsubsection{Socioeconomic Consequences of Irregular Migration}

As to David (2000) the most common impacts of irregular migrants are exploitative working and worse living conditions they face at the place of destination. Respondents' evidence shows that long working hours, unlimited workload, restricted movement, inability to change employers, denial of wages, and irregular payment of wages are among socioeconomic impacts of irregular migration. Migrant workers are expected to work for excessively long hours per day and are not allowed sufficient spare time. Their freedom of movement and correspondence outside the family is additionally limited through reallocation of visas and work grants, and additionally through observing their contacts with others. Migrant workers do not have access to sufficient food during their stay at the place of destination. Victims of trafficking do not have access to medical care, too. They are asked to work even when they are too ill; and CLANDESTINO (2009) supports this idea stating that irregular migrants face the greatest risks of poverty and social exclusion, and therefore, they are vulnerable and often marginalized from society. This situation is fostered by restricted access to basic social services (e.g. health care, education, and housing) that they usually face. The evidence indicates that irregular migrants are also forced into illegal activities, such as commercial sex, and drug and alcohol trafficking. This is usually done once the victims are rendered undocumented through taking away their passport and other travel documents. In the course of their journey some die from hanger, some from oxygen loss in the container, and some others from sinking in the water. Because robbery is so serious in South Africa those who make private businesses are robbed their monies and belongingness and some are even killed. Vulnerability for killings and organ removal is commonly known and repeatedly reported when migrants travel via northwestern route to European countries.

Family of irregular migrants faces negative impact directly or indirectly. Every aspect of the victim's hazardous situation has an impact on the situation of their family. Family members support the migration of the victim in the expectation that they will soon be refunded by the migrant. This is because migration for economic motives is viewed as an investment in human capital, which entails both direct and indirect costs as well as the expectation of returns in the form of increased earnings in the destination. This is likely to involve selling of their assets and belongingness and this will be resulted in absolute loss of basic necessities.

\subsubsection{Political Consequence of Irregular Migration}

The consequences of irregular migration are not limited to migrant and their family; it also affects the society at large. The societal level consequences are in fact long-lasting and are known through time goes. Available evidences show that loss of productive workforce, social problems arising from broken families and children growing up without a parent or parents, as well as the growing instability of the migrants and their families in the contexts of dependency on earnings from country. As indicated in the respondents' data young people with limited 
education are vulnerable to trafficking and smuggling and they are more likely to migrate for employment abroad. If the problem is not adequately addressed, and protection is not available to fight against the incidence, then the government might loss public confidence and trust. Diplomatic dispute is another type of political consequence of irregular migration. When the government of origin country blames mistreatment and abuse of migrants at the destination country, then their diplomatic relationship becomes adversely rough; even they block and restrict their diplomacy. Typical example indicted by respondents was the case of 28 Ethiopian migrants' massacre by terrorists in Libya in 2015 so that it led the countries to diplomatic dispute and Ethiopia blocked its diplomatic relationship with Libya as well.

\subsubsection{Psychological Consequences of Irregular Migration}

Respondents' evidence shows that sexual and emotional abuse is prevalent especially on women migrants. Because of vulnerability for sexual harassment, most of women migrants are raped by either traffickers and smugglers or their employers. Therefore, this may cause unwanted pregnancies and other health hazards. On the other hand, female employers would further physically abuse the migrant when they hear that their husband or another member of the family has sexually attracted by the migrant worker. Henceforth they develop inferiority and hopelessness and they loss sense of self-esteem. They said that emotional abuse is the most common and humiliating type of the abuses. When employers refuse to pay wages, humiliate and isolate them, then migrant workers become mentally disturbed, and this may lead to permanent personality disorders involving loss of sense of self-esteem, mental illness and depression. Available evidences indicate that migrants develop fear and helplessness especially in South Africa due to killings and continuous robbery. Typical example stated by respondents was the 2015 xenophobic movement at Durban, South Africa; where many Ethiopian migrants were killed and robbed.

\subsubsection{Physical Impacts of Irregular Migration on Migrant}

Physical abuse is another commonly used method by employers to instill control and obedience. One key informant raised the possible occurrence of organ removal. Physical abuse and the absence of medical care, result in untreated physical injuries, even death. Community members and key informants' evidences indicates that there are some cases where victims returned with serious physical injuries, such as a broken legs and arms or death without any explanation. Some who are unable to survive the pressure and abuse they suffer, hurt themselves when trying to escape by jumping from high apartments where they live; while others try to commit suicide by swallowing poisons. In the majority of cases the migrants suffer from physical injuries such as broken limbs, burns on their skins, malnourished physical appearance, broken legs and arms so that opportunities for personal development, intellectual advancement and motivation for growth are lost.

\section{Recommendations}

The authors propose the following suggestions:

1) Federal Democratic Republic of Ethiopian Government, Ministry of Education ought to ratify and practically apply innovation based educational policy in order to develop technology so as to maintain industrial led economy; and this creates better employment opportunity.

2) Federal Democratic Republic of Ethiopian Government, Ministry of Health and Social Affairs need to ratify and practically apply anti-netlist (child number limiting policy) and civil registration of birth, marriages, and death because families having limited number of children are more likely to have higher incomes, increased basic needs, greater saving capacity, and higher educational achievement. Civil registration of birth, marriages and death enhances data documentation of family details.

3) Federal Democratic Republic of Ethiopian Government, Ministry of Finance and Economy should make civil servants' salaries and wage benefit relatively as equivalent as major destination countries.

4) Federal Democratic Republic of Ethiopian Government, Ministry of Education need to include the issue of migration in the curriculum and student's text books so that the learners identify the difference between legal and irregular migration and aware of the burden which irregular migration brings.

5) Federal Democratic Republic of Ethiopian Government, Ministry of Finance and Economy had better create loan opportunities and microfinancing enterprises for youth to start domestic jobs.

6) Federal Democratic Republic of Ethiopian Government, Ministry of Immigration and Foreign Affairs should institutionalize the problem; build accountability and transparency system among public officials who are responsible for tackling the problem.

7) Federal Democratic Republic of Ethiopian Government in collaboration with bank and financing institutions need to build rental homes with small scale payments to enhance those who are with problem of little earning on town and city areas so that they can afford for their basic need.

8) Federal Democratic Republic of Ethiopian Government, Ministry of Immigration and Foreign Affairs should do their better to improve border management system such as physical borders and electronic surveillances, security feature and inspections, border guards' training and application of modern checking machines.

9) Federal Democratic Republic of Ethiopian Government should avoid shortage of financial and human resources and support sector offices through budgeting and updated training. 
10) Judicial branches, the police, women and children affairs officers, Southern Ethiopian Region Security, Immigration and Refugee Affairs Authority as well as other stakeholders need to work in collaboration and cooperation to increase efficiency of policy implementation.

11) Judicial branches, the police and Southern Ethiopian Region Security, Immigration and Refugee Affairs Authority ought to collect data on the incidence of irregular migration, increase reporting, investigation and prosecution of irregular migration cases.

12) Federal Democratic Republic of Ethiopian Government has to draw poverty reduction strategies and expand domestic investments to create wide job opportunities.

13) Southern Ethiopian Region Women and Children Affairs Officers in collaboration with population media such television and radio broadcasting have to create awareness on the public about the burden of irregular migration.

\section{Summary}

Socio-economic, political and demographic causes and consequences of irregular migration, policy gaps that contribute to the problem, and policy implementation problems were explored in this study. Chronic unemployment and underemployment, poverty, better wage benefits and good public services at destination countries, failure in educational endeavours and illiteracy rate, awareness gaps, large family size, adolescence and puberty age, lack of loan or credit facilities to start job and negative attitudes towards local domestic work are found to be socioeconomic and demographic factors that caused irregular migration in southern Ethiopian region. Impacts of irregular migration on migrants and their families as well as on the country they belong to were investigated.

Absence of border management strategies and action plans, lack of clear and organized hierarchy of public officials who are responsible for taking actions on the incidence; absence of child number limiting, birth, death and marriage registration policy are found to policy gaps that affected implementation of irregular migration policy. Fluctuating and conditional data collection on the incidence of irregular migration; limited collaboration and cooperation between/among higher and local public officials as well as other stakeholders adversely; and shortage of financial and human resource, lack of training to detect forged (falsified) documents at border areas are among obstacles to effective policy implementation.

Finally based on the findings policy priorities and implementation strategies are recommended to Federal Democratic Republic of Ethiopian Government's Ministry Education, Health and Social Affairs, Finance and Economy, Immigration and Foreign Affairs, and Southern Ethiopian Region Judicial branches, the police, women and children affairs officers and other stake holders for further review, ratification and application of policy of irregular migration to protect against the problem.

\section{References}

Anbesse, B., Hanlon, C., Alem, A., Packer, S., and Whitley, R.,'Migration and Mental Health,' A Study of LowIncome Ethiopian Women Working in Middle Eastern Countries, Vol. 55, No. 6, 2009, pp.557-568.

Blue Campaign, 'What is Human Trafficking?, ' (2016), http://www.dhs.gov/blue-campaign/what-human trafficking

Boyd, M., 'Family and Personal Networks in International Migration,' Recent Developments and New Agendas, Vol. 23, No. 3, 1989, pp. 638-672.

Central Statistics Agency of Ethiopia, The 2007 Population and Housing Census of Ethiopia, 2007 (Addis Ababa, Ethiopia: Central Statistics Agency of Ethiopia Printing Office, 2007), pp. 4-85.

CLANDESTINO, 'Database on Irregular Migration,' (2012), http://irregular- migration.net/6, 2012

Danish Refugee Councel, 'Ethiopia Country Profile,' (2016), http://reliefweb.int/report/ethiopia/ethiopia-countryprofile-updated-may-2016,

David, F., 'Human Smuggling and Trafficking,' An Overview of the Response at the Federal Level, Vol.24, 2000, pp. 9-13.

Emebet, K., 'An Assessment of the International Labor Migration Situation, the Case of Female Labour Migrants,' Working Paper of Gender Promotion Programme, International Labor Office, Addis Ababa, Ethiopia, March $1,2002$.

Endeshaw, Y. Gebeyehu, M. \& Reta, B. Assessment of Trafficking in Women and Children in and from Ethiopia. International Organization for Migration, n.d, 8-85

E-source.Social and Behavioral Theories. http://www.esourceresearch.org/eSource Book/SocialandBehavioralTheories/3TheoryandWhyItisImportant/tabid/727/Default.aspx,n.d

Fatemi, M.and Behmanesh, M. New Public Management Approach and Accountability. International Journal of Management, Economics and Social Sciences, 2012, 1(2), $42-49$

Federal Negarit Gazette of FDRE. Prevention and Suppression of Trafficking in persons and smuggling of migrants proclamation. Negarit Gazette, 2015

Hood, C. Contemporary public management: a new global paradigm. Public Policy and Administration, 1995, 
10(2), 104-117

Horwood, C. Irregular Migration Flows in the Horn of Africa: Challenges and implications for source, transit and destination countries. Research Programme, 2015, 18|2015, 7-49

International Council on Human Rights Policy. Irregular Migration, Migrant Smuggling and Human Rights: Towards Coherence. Geneva: International Council on Human Rights Policy, 2010

International Labour Organization-ILO. Trafficking in Persons Overseas for Labour Purposes: The Case of Ethiopian Domestic Workers. Addis Ababa: ILO, 2011

International Organization for Migration-IOM. Mission to Ethiopia. https://ethiopia.iom.int/, 25 Nov, 2009

International Organization for Migration-IOM. Irregular Migration and Mixed Flows: Background paper. IOM, Switzerland, 2010, 5-15

International Organization for Migration-IOM. Key Migration Terms. http://www.iom.int/key-migration-terms, 2011

International Organization for Migration-IOM. Key Migration Terms. http://www.iom.int/key-migration-terms, 2016

Interpol. Connecting Police for a Safer World. http://www.interpol.int/Crime-areas/Trafficking-in-humanbeings/People-smuggling, 2016

Koser, K. Irregular migration, state security and human security. Global Commission on International Migration, University College London, 2005, 7-18

Laczko, OF. Human Trafficking: The Need for Better Data. Migration Policy Institute, 2002, 1, 3-9

Massey,D.S.,Arango,J.,Hugo,G.,Kouaouci,A.,Pellegrino,A.,Taylor,J.E. An Evaluation of International Migration Theory: The North American Case. Population and Development Review, 1994, 20/4, 699-741

Messele, R. and Gebeyehu, M. 'Baseline assessment on trafficking in persons: Prevention and response in Ethiopia.' IOM Addis Ababa, 2015, Unpublished

Mohammed, Y.Cause and Consequence of Cross Border Illegal Migration from South Wollo, Ethiopia. Arts and Social Sciences Journal, 2016, 7, 4-17

OECD. Public Management Development Survey. OECD, 1995, 95, 11-17.

Play Therapy Africa Ltd. Trafficking in Persons Overseas for Labour Purposes: The Case of Ethiopian Domestic Workers. International Labour Organization-ILO, 2011, 7-27

Skeldon, R. Myths and Realities of Chinese Irregular Migration. International Organization for Migration, 2000 , $1 / 22,7-36$

Teshome, D., Ajay, B., and Charles, H. Irregular Migration: Causes and Consequences of Young Adult Migration from Southern Ethiopia to South Africa. XXVII IUSSP International Population Conference, Busan, South Korea, 26-31 August, 2013, 15-37

The Guardian. People Smuggling: How it Works, Who Benefits and How it can be Stopped. http://www.theguardian.com/globaldevelopment/2015/jul/31/people-smuggling-how-works-who-benefitsand-how-to-put-stop, 2016

U.S.Immigration and Customs Enforcement. Investigating Illegal Movement of People and Goods. https://www.ice.gov/human-smuggling, Dec, 2016

United Nations-UN. Irregular Migration, Human Trafficking and Refugees. International Migration Policies, United Nations Department of Economic and Social Affairs, 2013, 91-96

United Nations High Commissioner for Refugees (UNHCR). Mixed Movements and Irregular Migration from the East and Horn of Africa and Great Lakes Region to Southern Africa. Regional Conference on Refugee Protection and International Migration, Dar es Salaam,Tanzania, 2010, 8-29

United Nations-UN. Smuggling of Migrants, A Global Review and Annotated Bibliography of Recent Publications. New York, United Nations Office on Drugs and Crime, 2011

Verbeek, M. A Guide to Modern Econometrics. 2nd edition, Erasmus University Rotterdam Press, 2004

Vollmer, B. Irregular Migration in the UK: Definitions, Pathways and Scale; the migration observatory, oxford university Press, 2011

Wakgari, G. Causes and Consequences of Human Trafficking in Ethiopia: The case of Women in the Middle East. International Journal of Gender and Women's Studies, 2014, 2/2, 233-246

Wikipedia, the Free Encyclopedia. Human Trafficking.

https://en.wikipedia.org/wiki/Human trafficking, Dec, 17, 2016

World Bank. Poverty Assessment. Ethiopia, The World Bank Group, 2015

Yin, R. K. Case study research: Design and methods. Thousand Oaks, CA: Sage, 2003, 3, 1-2 